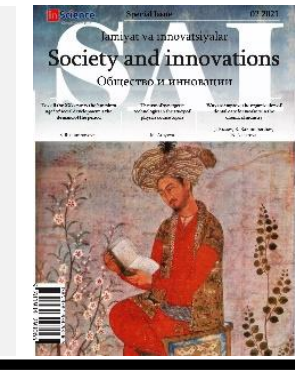

\title{
The importance of using picture dictionaries in the lessons of mother tongue in primary schools
}

\section{Mukhtaram KHUSENOVA ${ }^{1}$ Manzura ERNAZAROVA ${ }^{2}$}

Siberian institute of management

\begin{tabular}{l} 
ARTICLE INFO \\
\hline Article history: \\
Received January 2021 \\
Received in revised form \\
15 January 2021 \\
Accepted 20 February 2021 \\
Available online \\
7 March 2021
\end{tabular}

\section{Keywords:}

picture dictionary,

mother tongue,

lessons,

words,

teaching,

visual dictionary.
ABSTRACT

The following article gives the description of picture dictionaries. And it also introduces picture dictionaries as a useful material for children to immerse their mother tongue. The vitality has been emphasized in the following article.

2181-1415/C 2021 in Science LLC.

This is an open access article under the Attribution 4.0 International (CC BY 4.0) license (https://creativecommons.org/licenses/by/4.0/deed.ru)

\section{Бошланғич синфларда она тили дарсларида расмли луғатлардан фойдаланишнинг ахамияти}

\section{Калит суцзлар:}

расмли луғат,

она тили,

дарслар,

сўзлар,

ўқитиш,

курргазмали луғат.

\section{АННОТАЦИЯ}

Қуйидаги мақолада расм луғатлари тавсифи берилган. Шунингдек, расм луғатларини болаларнинг тилини сингдириш учун фойдали кўргазмали қуроллар сифатида киритади. Мақолада амалиётда қўлланилиши хақида батафсил маълумотлар келтирилган.

\footnotetext{
${ }^{1}$ Dsc, docent, Navoi State Pedagogical Institute, Tashkent, Uzbekistan

2 Master's degree, Navoi State Pedagogical Institute, Tashkent, Uzbekistan
} 


\section{Важность использования графических словарей на уроках родного языка в начальной школе}

\author{
Ключевые слова: \\ картинный словарь, \\ родной язык, \\ уроки, \\ слова, \\ обучение, \\ визуальный словарь.
}

\section{АННОТАЦИЯ}

В следующей статье дается описание графических словарей. И это также вводит словари с картинками в качестве полезного материала для детей, чтобы погрузиться в свой родной язык. Жизненность была подчеркнута в следующей статье.

\section{INTRODUCTION}

A picture dictionary or pictorial dictionary is a dictionary where the definition of a word is displayed in the form of a drawing or photograph. Picture dictionaries are useful in a variety of teaching environments, such as teaching a young child about their native language, or instructing older students in a foreign language, such as in the Culturally Authentic Pictorial Lexicon. Picture dictionaries are often organized by topic instead of being an alphabetic list of words, and almost always include only a small corpus of words.

A picture dictionary or a visual dictionary relies on pictures to show the meaning of words. Obviously, these words often teach nouns, although there are visuals to demonstrate abstract ideas like emotions as well. Unlike regular dictionaries, visual dictionaries are not arranged alphabetically but are instead organized thematically, with an image linked to each theme. There are usually a number of themes on which these dictionaries are based, but the dictionary usually has thousands of images to help you understand words. Children can look for the themes to find the words easily. Some of these dictionaries are multi-lingual, but others are monolingual. These dictionaries also have an index of all the words defined. It should help you find the words you need by finding the right illustration.

Visual dictionaries can be used by all kinds of people, including teachers, students, translators, and even parents. Skill level is not a factor with these dictionaries either, as anyone can benefit from using these dictionaries.

\section{MATERIALS AND METHODS}

The following article uses different kind of dictionaries as a resource for research work. Also, the examples have been taken from real picture dictionaries that can be used in mother tongue lessons.

\section{RESEARCHES}

$\checkmark$ Learning mother tongue vocabulary through a visual dictionary is important if you are trying to learn about a certain profession. The dictionary helps you study a certain theme faster than a normal dictionary would. For instance, if you are in the medical profession, you can learn a lot about the body with images that illustrate many such parts in a single labeled graphic.

$\checkmark$ A picture dictionary is also great if you want to have a better idea of how certain things work, for instance, you can learn how an engine works based on how various parts 
are connected to each other. A visual dictionary is also good at helping create a context for words that would be otherwise confusing to you.

$\checkmark$ Another benefit to learning mother tongue through pictures is that it makes mastering vocabulary more interesting. Naturally, we respond better to images than to texts and words. For this reason, you can learn faster if you use a visual dictionary. Therefore, if learning new words through a regular dictionary is not exciting enough for you, you can always start using a picture dictionary to make the process of mastering new vocabulary more interesting for you.

In many developing countries, a significant proportion of children enter school not speaking the language of the classroom. Many education systems favour using national or 'global' languages instead of mother-tongue teaching. Education is often carried out in the old colonial language, or an international language, such as English. This is based on the belief that certain internationally 'important' languages give children a competitive advantage in later life. In other countries, education is taught in the dominant language of a main linguistic group, sometimes at the expense of more marginalized ethnic or linguistic groups. In far too many countries, the educational basics - textbooks, learning materials and the teacher's language of instruction - are primarily or entirely available only in nonmother-tongue languages. Sometimes, in multilingual countries with many local languages, teachers themselves do not speak the local language which children learn at home, and speak the dominant language. In other cases, the teachers themselves may not be fully proficient in the language of instruction. Children in remote rural areas, who speak one language at home and have no contact with the school language outside of the classroom, often have the biggest problems in gaining any understanding of the language taught at school. Children need to be engaged in and excited about reading and learning and this can only be done if the materials are ones which they will understand and enjoy. In most developing countries, the only reading material children see are school textbooks, which are often in very short supply. Other materials to support learning are hardly ever available. Without access to good materials, children struggle to become literate and learn. Best picture dictionaries would here help easily. In most low- and middle-income countries, the majority of primary schools have no library, and books are luxuries which families cannot afford. Learning to read requires a range of complex skills, all of which need the right use of suitable materials. These skills include recognising sounds, connecting sounds to symbols, developing vocabulary, understanding the content and developing fluency. As children's language capacity develops, materials with increasing difficulty are required. Materials need to contain cognitively challenging content so that as children acquire knowledge, skills and concepts through their mother tongue, achievement in all subject areas will improve. The availability of good learning materials, written in a language and with a context that is relevant to children is vitally important; a lack of such materials has a profoundly negative effect on children's learning and on literacy achievement levels. Sadly, even where mother-tongue materials are used, often not enough resources are channelled towards it for programmes to fully succeed. Such programmes will inevitability break down if there are insufficient materials in local languages. Without adequate materials the teaching of early literacy skills is extremely challenging and developing fluency is all but an impossible task. The inclusion of local and indigenous knowledge in texts and reading materials requires research with community participation and the only way to produce good material resources in the mother-tongue is by members 
of the language community themselves. There may be a lack of skilled authors and editors for the local languages, but capacity could be strengthened through training and experience. In many places the development of mother tongue literature has been promoted through writing contests, festivals, book signings, writing and illustration workshops, debates and radio and television programs.

Local artists can produce illustrations related to the text which are also appropriate to the local context.

\section{RESULTS}

Although there is very little research evidence of how dictionaries are used by learners during the acquisition process, there is a large body of practical experience available of using dictionaries under test conditions from which we can draw more general conclusions about the potential for the learning process.

Just at the moment when schools and colleges have received a blow to their motivation to continue to develop the teaching of dictionary skills during the learning process, interest in this skill in Higher Education has grown.

\section{The information that occur in dictionaries}

1. Meaning

3. Gender

4. To cross check meaning

5. Use in context or specialised use (eg medical)

6. Spelling forms of nouns/adjectives

7. Synonyms/alternatives

8. Appropriate use with other words

9. Verb forms [endings, tenses]

10. Register

11. Pronunciation (phonetics)

The low rate of usage of the dictionary for productive skills or for introducing greater variety of or appropriateness of language into written work stands out in this rank order.

Dictionaries tend to be used mostly for checking and for looking up meaning. Such findings are largely in accord with what most experienced teachers and tutors would predict and have observed in their classes.

If we wish to extend the use that students make of their dictionaries from the largely passive one of verification to the more productive one of a resource for learning and for increasing vocabulary acquisition, then it is clear that there is a need both for raising awareness of the potential and for more specific training.

Ensure that whichever picture dictionary you buy, you should familiarize yourself with what it has to offer. The Introduction or Preface to a dictionary contains useful advice on how to find your way around the entries.

Each dictionary uses similar, but not identical symbols and conventions to give you information about the words you are looking up. Make sure you know what they are by reading the user guide in the front of your dictionary. A large amount of information is given about the words you look up; make sure you know what the potential is. 
If we are to take advantage of the huge resource as a study aid which the picture dictionary represents in primary schools in mother tongue classes, then it is important that research be done into creating effective training programmes.

Publishers of dictionaries have a part to play in this development. The style of the introductions and the design of entries are important elements in making the use of dictionaries more accessible to all learners.

\section{Discussion of Tips for Using Picture Dictionaries}

Identify a page in the picture dictionary that seems relevant to your student's life. Identify 5 words you think your student would like to learn (see if s/he can point to the page/pictures that she is interested in learning about).

$\checkmark$ Point to each picture and say the word associated with the picture. Repeat this several times with approximately 5 words (per lesson).

$\checkmark$ Speaking: Have the student point to the picture when you say the word. Repeat this several times.

$\checkmark$ Reading: Point to the word associated with the picture and then point to the picture. Point to the first letter of each word and say the letter. Repeat this several times for each of the 5 words.

$\checkmark$ Ask your student to say the first letter as you point to each word/picture. Write the words on a piece of paper \& see if your student can read the words and/or point to the picture associated with the words.

$\checkmark$ Writing: Write the words on lined paper. Have your student copy the words, then write them a few times. Use these words for the activities to follow.

Learning activities in picture dictionaries in mother tongue classes for all students:

1. Matching: Draw the pictures on left side of a piece of paper (have your student help with this) Write the words on the ride side of a piece of paper (in different order) Have your student draw a line to match the picture and drawing.

2. Create flashcards. Use index cards or cut up pieces of blank white paper. Write a vocabulary word on one side of each card. On the other side, draw a picture of the person, place or thing. Have your student help with this. Use these to help your student practice saying the word when seeing the picture and also when seeing the word.

3. Create a concentration/memory game. Make 5 pairs of one-sided flash cards: one card should have a word with no picture, and the other card should have a picture with no words. Make a pair for each vocabulary word (using five words). Turn all the cards face down on a table and then choose two cards. The goal of the game is to try to find two that match: a word with a picture. If they do not match, say the word, (e.g., "bread - bread"). If they do not match, say the word for each card anyway for practice, (e.g., "bread - milk").

4. Create a listening game. Put the cards all down on the table picture side up. Say a word and have your student choose and pick up the card that you have named. Try this again with the written word side showing (no pictures this time).

5. Create a letter scramble. Choose one of the five words (choose a word with five or less letters). Write each of the letters on a separate index card or piece of blank paper. Show the student how the letters are arranged in order. Say the word and reinforce the meaning by pointing to the picture. Scramble the letter cards and model how to put them 
back in order. Scramble them again and see if your student can arrange the letters, with or without looking at a model of how the word is spelled.

A little more: Have your student do this with several words, one at a time, and glue the letters down onto a sheet of colored paper when they are finished to make a review sheet.

For more advanced students: Spread out the letters for 3-5 words at once. Have your student spell the words using the letter cards.

6. Work on writing the first letter. Write the first letter of the word large on large lined paper.

Model how to write the letter several times. Have your student practice writing the letter many times on the page. Circle the best one.

7. Same or different? Working with letters. Write a row of copies of the first letter. Make the first one correct but include several errors in the next ones. Sometimes write the letter upside down, backwards, or with missing pieces. See if your student can circle the letter only when it appears correctly, matching with the first.

\section{List of used literature}

1. https://7esl.com/picture-dictionary/

2. Effects of Picture Dictionaries on Children's Early Language and Literacy Development (page 10) Shahidullah Sharif

3. http://users.sch.gr/evpapalex/wordpress/category/learn-whileplaying/picture-dictionary

4. Tips for Using Picture Dictionaries, Refugee Transitions and Dion Zizak 